\title{
Outbreak
}

\section{Successful public health response to four cases of imported measles in Panama}

\author{
Néstor Sosa ${ }^{1}$, Ilka Guerra ${ }^{1}$, Leyda Abrego ${ }^{1}$, Julio Cisneros ${ }^{1}$, Juan Castillo ${ }^{1}$, Javier Nieto ${ }^{1}$, Carlos \\ Gálvez $^{2}$, Yadira Moltó ${ }^{2}$, Rebecca E Smith ${ }^{1}$, Juan Miguel Pascale ${ }^{1,3}$ \\ ${ }^{1}$ Gorgas Memorial Institute for Health Studies, Panama, Republic of Panama \\ ${ }^{2}$ Epidemiology Department, Ministry of Health, Panama, Republic of Panama \\ ${ }^{3}$ Microbiology Department, School of Medicine, University of Panama, Panama, Republic of Panama
}

\begin{abstract}
In Panama, the last endemic cases of measles occurred in 1995. In this paper, we report four cases of imported measles in three girls and one boy after they returned from a trip to Poland and Israel between 28 April and 11 May 2011. The etiologic diagnosis of the four cases was confirmed by detection of IgM antibodies against measles virus and positive polymerase chain reaction using measles-specific primers. All cases had genotype D4 with close genetic similarity to virus reported from Poland. Public health interventions included isolation of the cases in their homes and an extensive search for and vaccination of contacts of the four cases, regardless of their vaccination status. A nationwide vaccination campaign was also implemented after the first case was identified. A total of 70,950 measles vaccine doses were administered in Panama in the two months following the identification of these cases. In addition, 94,179 persons were confirmed to have their immunization schedule up-to-date and did not receive the vaccine. No secondary cases were detected in Panama in the following six months.
\end{abstract}

Key words: measles; infectious disease outbreaks; Panama; communicable disease control; travel medicine

$J$ Infect Dev Ctries 2012; 6(8):605-610.

(Received 01 March 2012 - Accepted 12 May 2012)

Copyright (C) 2012 Sosa et al. This is an open-access article distributed under the Creative Commons Attribution License, which permits unrestricted use, distribution, and reproduction in any medium, provided the original work is properly cited.

\section{Introduction}

Measles virus is one of the most highly contagious pathogens and has caused millions of deaths throughout human history. Since the introduction of live-attenuated vaccines in the $1960 \mathrm{~s}$ [1], the number of measles cases has declined significantly, and the World Health Organization (WHO) has set the goal of reducing the number of deaths attributable to measles by $90 \%$ by 2015 [2].

The WHO Region of the Americas has eliminated endemic measles transmission with intensive vaccination and surveillance efforts [1]. Recently, however, numerous reports of imported cases of measles have occurred in different countries in this region: for example, in the period between 2001 and 2010, of 692 measles cases reported in the United States of America, 604 (87\%) were importassociated [3], and during the first 19 weeks of 2011, a total of 118 cases of imported measles were reported in the USA. Most of these cases came from Europe and South-East Asia.

In1995, the last case of endemic measles transmission occurred in Panama, 22 years after the introduction of the measles monovalent vaccine to the National Vaccination Program. At present, this program recommends Measles, Rubella and Mumps (MMR) live-attenuated vaccine at 12 months and a second dose between 4 and 5 years of age. Measles vaccination coverage in Panama for the first dose is $95 \%$ [4]. Approximately $10 \%$ of the population receives vaccination at private pediatric offices.

We report four imported cases of measles in vaccinated children from Panama after they visited Poland and Israel, and the public health measures taken to prevent further spread of the disease.

\section{Case report}

In May 2011, four adolescent children developed signs and symptoms that suggested measles upon returning to Panama after a 15 day cultural trip to Poland and Israel. There were a total of 94 participants in this travel group. The group started their trip on 27 April 2011 in Panama and arrived in Warsaw, Poland, on 28 April 2011, via New York and London. On 4 May, they continued their travel to Tel-Aviv, Israel. In both countries they visited 
numerous historical and religious sites. They returned to Panama, via New York, on 11 May 2011.

The four children, three girls and one boy, were not related to each other but had travelled together and were in contact with numerous other peers during this trip. All resided in an affluent neighborhood of Panama City and three attended the same high school. Three of the four subjects had received at least two doses of either measles or MMR vaccine, while one subject had received only one dose of MMR according to their medical charts and vaccination cards (Table 1). All the vaccines had been given at different private offices between 1994 and 2002 .

The first of this group of affected subjects developed fever on 10 May, one day before her return to Panama. All four had developed fever by 16 May and all had developed the typical cephalocaudal maculopapular rash by 17 May 2011 (Figure 1). The clinical diagnosis of measles was made between 5 and 7 days after their arrival in Panama (Table 1). One case was hospitalized for 48 hours for closer observation, but none of the four patients developed complications.

Acute serum was obtained from all four subjects. The etiologic diagnosis of each case was confirmed by detection of IgM antibodies against measles virus (Siemens Enzygnost Anti-Measles Virus/IgM EIA; Tarrytown, New York, USA), and a positive polymerase chain reaction (PCR) using measlesspecific primers: MV64 (5'TATAACAATGATGGAGGGTAG-3') and MV59 (5'-GATATGTGACATTGATACATATAT-3') for the RT-PCR step, and primers MV60 (5'GCTATGCCATGGGAGTAGGAGTGG-3') and MV63 (5'-GGCCTCTCGCACCTAGTCTAG-3) for the nested PCR [5]. Genotyping and sequencing were performed using extracted RNA from nasopharyngeal swabs from all four cases. All cases were genotype D4 with close genetic similarity to virus reported from Poland (Figure 2). Nasopharyngeal swab and urine samples were also inoculated in Vero/hSlam cells [6,7] and measles virus was successfully isolated in two of the four cases using standard protocols [8]. Measles virus genotypes were confirmed as D4 by RT-PCR and sequencing of the isolates obtained following previously reported protocols [5]. Detection of IgG antibodies was attempted using a commercial kit (Siemens Enzygnost Anti-Measles Virus/IgG EIA; Tarrytown, New York, USA), but acute serum results were negative in all four cases.
The Epidemiology Department of the Ministry of Health conducted an epidemiological investigation to identify contacts of these subjects and to detect secondary cases. All four cases were quarantined in their homes during their acute illness.

A total of 809 close contacts of the four affected subjects were interviewed and followed until 28 June (42 days after the last case) to detect symptoms compatible with measles. These included contacts that occurred during the hospitalization of the index case. Among persons who were in contact with these four cases, there were five subjects with rash, but measles was excluded in all of them after laboratory testing. Furthermore, during the period from 22 April 2011 (21 days prior to identification of the first case) to 28 June, 129 suspicious cases, including the 5 symptomatic contacts, were detected by the MeaslesRubella Surveillance System of the Ministry of Health. In all but the four cases described in this report, however, the diagnosis of measles was ruled out.

The two schools of the affected subjects were also visited during the investigation. Students and teachers were interviewed and alerted to the signs and symptoms of measles. The total number of persons interviewed during the school investigations was 4492. Additionally, 160 of the 177 passengers on the New York-Panama return flight were contacted and followed once the index case was identified. No investigation was conducted among the passengers of the Tel-Aviv to New York portion of the return flight.

A massive vaccination campaign was implemented for all eligible persons regardless of their exposure history. A total of 70,950 vaccine doses were administered in the country in the two months following identification of the first case. These included 12,783 in the metropolitan area, where contacts and classmates of the cases resided. An additional 94,179 persons were confirmed to have their immunization schedule up-to-date and did not receive the vaccine. No additional cases of measles have been confirmed in the country since this outbreak.

\section{Discussion}

This report underscores several important aspects of measles epidemiology in a country where endemic measles transmission has ceased.

First is the risk of travellers importing measles to other countries from regions where measles transmission is ongoing. Commonly we associate the 
Table 1. Summary of the clinical and epidemiological characteristics of the cases of measles reported in Panama

\begin{tabular}{|c|c|c|c|c|c|c|c|c|c|}
\hline $\begin{array}{c}\text { Case } \\
\text { Number }\end{array}$ & Gender & $\begin{array}{c}\text { Age } \\
\text { (years) }\end{array}$ & $\begin{array}{l}\text { Date of First } \\
\text { Symptom }\end{array}$ & Signs/ Symptoms & $\begin{array}{c}\text { First Dose/Age/ } \\
\text { Vaccine Type }\end{array}$ & $\begin{array}{c}\text { Second } \\
\text { Dose/Age/ } \\
\text { Vaccine Type }\end{array}$ & $\begin{array}{l}\text { Viral Culture } \\
\text { (Date of the } \\
\text { Sample) }\end{array}$ & $\begin{array}{l}\text { Internal } \\
\text { Reference } \\
\text { Code }\end{array}$ & $\begin{array}{c}\text { Genbank } \\
\text { Accession } \\
\text { Number }\end{array}$ \\
\hline 1 & $\mathrm{~F}$ & 17 & 10 May 2011 & $\begin{array}{l}\text { Fever, Rash, } \\
\text { Coryza, } \\
\text { Koplik's Sign, } \\
\text { Conjunctivitis, } \\
\text { Cough }\end{array}$ & $\begin{array}{c}\text { 09 Dec } 1994 \\
\text { (Age: } 12 \text { mo) } \\
\text { Monovalent }\end{array}$ & $\begin{array}{c}16 \text { Dec } 1996 \\
\text { (Age: } 3 \text { years) } \\
\text { MMR }\end{array}$ & $\begin{array}{c}\text { POSITIVE } \\
\text { (16 May 2011) }\end{array}$ & 9062 & JN392455 \\
\hline 2 & $\mathrm{~F}$ & 16 & 12 May 2011 & $\begin{array}{l}\text { Fever, Rash, } \\
\text { Coryza, } \\
\text { Conjunctivitis }\end{array}$ & $\begin{array}{c}25 \text { May } 1995 \\
\text { (Age: } 12 \text { mo) } \\
\text { Monovalent }\end{array}$ & $\begin{array}{c}\text { 09 Jan } 2002 \\
\text { (Age: } 8.5 \text { years) } \\
\text { MMR }\end{array}$ & $\begin{array}{l}\text { NEGATIVE } \\
\text { (17 May 2011) }\end{array}$ & 9075 & JN392456 \\
\hline 3 & $\mathrm{~F}$ & 17 & 13 May 2011 & $\begin{array}{c}\text { Fever, Rash, } \\
\text { Conjunctivitis, } \\
\text { Athralgias }\end{array}$ & $\begin{array}{c}\text { 04 June } 1994 \\
\text { (Age: } 10 \text { mo) } \\
\text { MMR }\end{array}$ & $\begin{array}{c}\text { NOT } \\
\text { RECEIVED }\end{array}$ & $\begin{array}{c}\text { POSITIVE } \\
\text { (17 May 2011) }\end{array}$ & 9077 & JN392457 \\
\hline 4 & M & 17 & 16 May 2011 & $\begin{array}{l}\text { Fever, Rash, } \\
\text { Koplik's Sign, } \\
\text { Conjunctivitis, } \\
\text { Cough }\end{array}$ & $\begin{array}{c}17 \text { Nov } 1994 \\
\text { (Age: } 11 \mathrm{mo}) \\
\text { Monovalent }\end{array}$ & $\begin{array}{c}30 \text { May } 1996 \\
\text { (Age: } 2.4 \text { years) } \\
\text { MMR }\end{array}$ & $\begin{array}{l}\text { NEGATIVE } \\
\text { (19 May 2011) }\end{array}$ & 9086 & JN392458 \\
\hline
\end{tabular}


Figure 1. Typical measles maculopapular rash, Index case, Day 4 of febrile illness

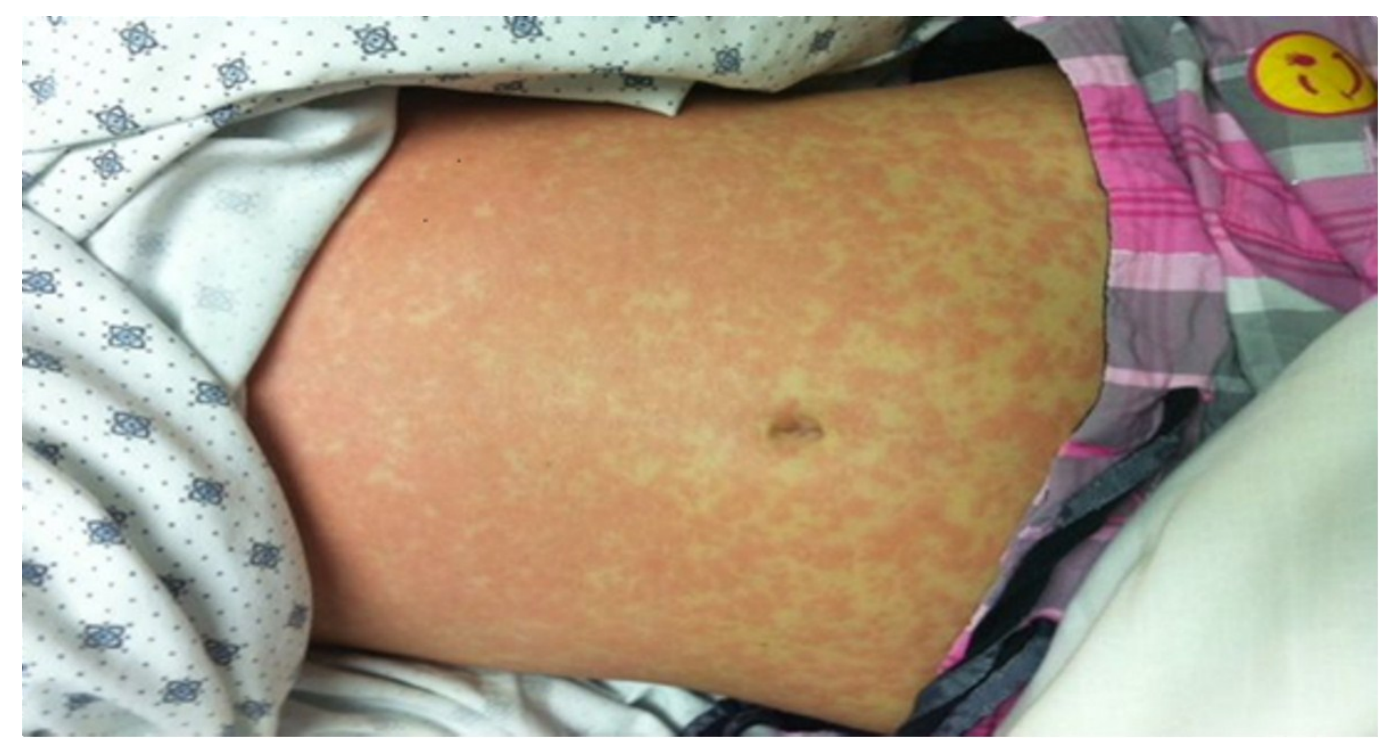

Figure 2. Phylogenetic analysis of the four cases of measles

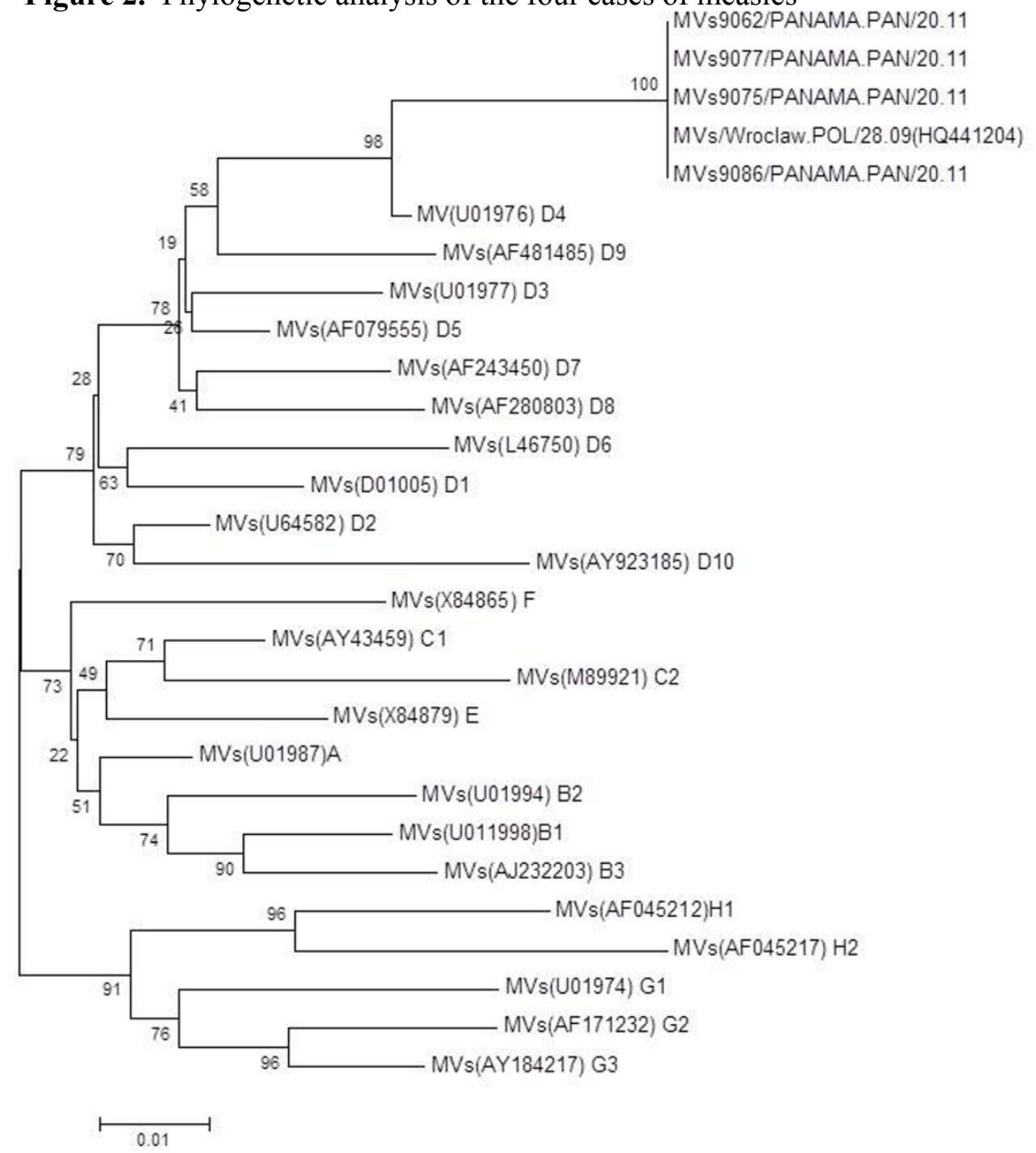

Phylogenetic analysis of the 456 nucleotides encoding the $\mathrm{COOH}$ terminus of the $\mathrm{N}$ protein of measles viruses detected in Panama, highlighting the sequences as genotype D4. The reference strains recommended by WHO and sequences previously isolated from Poland and identified as genotype D4 viruses were downloaded from GenBank and included for comparison. GenBank identification numbers are shown in parenthesis. The dendrogram was created with the MEGA 4 software by the neighbour-joining method with 500 bootstrap replicates. 
risk of infectious diseases with travel to lessdeveloped countries, and no specific preventive measures are considered for travellers from Panama to Europe. However, the WHO European region continues to have measles outbreaks, $[9,10]$, and a sizeable percentage of imported cases of measles in the US came from Europe in the period 2005-2008 [11].

The four cases reported in this study were caused by measles virus genotype D4. This genotype has been associated with imported sources of virus in the Americas and has also been reported frequently in Europe. In 2011, genotype D4 was the predominant genotype detected in 24 European countries $[9,12]$. Genetic sequencing of the virus isolated from the four Panamanian children showed $100 \%$ identity over 456 nucleotides to viruses reported in Poland in 2009. In fact, the index case developed symptoms six days after leaving this European country, within the incubation time of measles infection [13]. Thus consideration should be given to the administration of booster doses of measles vaccine before traveling to countries with ongoing cases of this disease.

Another important point is the susceptibility of vaccinated children to measles infection. Three of the four patients identified in this study had received two doses of measles vaccine. None of them had detectable IgG antibodies on presentation, nor were they protected from overt clinical disease. Primary and secondary vaccine failure has been reported extensively in the literature [14]. Immunologic immaturities at vaccination, waning vaccine-induced immunity and lack of immunogenicity of vaccines administered, due to failure of the cold-chain, for example, are common causes [15].

Finally, it is important to note that a significant and successful effort was made by Panamanian public health officials to contain this outbreak. The relatively rapid identification of the first case and isolation of the other three cases, combined with high measles vaccine coverage in the country, were important in preventing secondary infections. These factors are known to be important in preventing import-transmission [16, 17]. Public health interventions included the search for secondary cases plus immunization of numerous contacts regardless of their vaccination status.

\section{Patient consent and acknowledgements}

Consent was obtained from the patient and family for use of the photograph in Figure 1. This study was supported by the Gorgas Memorial Institute for Health Studies, Republic of Panama, and the Ministry of Health, Republic of Panama.

\section{References}

1. Castillo-Solorzano CC, Matus CR, Flannery B, Marsigli C, Tambini G, Andrus JK (2011) The Americas: paving the road toward global measles eradication. J Infect Dis 204 Suppl 1: S270-278.

2. WHO (2005) United Nations Children's Fund. Global immunization vision and strategy 2006-2015., Geneva, Switzerland: World Health Organization.

3. Cocoros NM, Zipprich J, Kuhles D, Rausch-Phung E, Shulte CR, Blog DS, Lurie P, Wiseman R, Kroll C, DeBolt C, Kutty PK, Redd SB, Barskey AE, Rota JS, Rota PA, Armstrong GL, Bellini WJ, Gallgher KM, Mahamud AS (2011) Measles imported by returning U.S. travelers aged 623 months, 2001-2011. MMWR Morb Mortal Wkly Rep 60: 397-400.

4. WHO (2011) Global Health Observatory Data Repository, 2011. http://apps.who.int/ghodata/?vid=80100. Accessed 30 December 2011.

5. Cheng WY, Lee L, Rota PA, Yang DC (2009) Molecular evolution of measles viruses circulated in Taiwan 19922008. Virol J 6: 219.

6. Tatsuo H, Ono N, Tanaka K, Yanagi Y (2000) SLAM (CDw150) is a cellular receptor for measles virus. Nature 406: 893-897.

7. Ono N, Tatsuo H, Hidaka Y, Aoki T, Minagawa H, Yanagi Y (2001) Measles viruses on throat swabs from measles patients use signaling lymphocytic activation molecule (CDw150) but not CD46 as a cellular receptor. J Virol 75: 4399-4401.

8. WHO (2006) Manual for the laboratory diagnosis of measles and rubella virus infection. http://www.who.int/immunization_monitoring/LabManualFi nal.pdf.

9. Martin R, Jankovic D, Goel A, Mulders M, Dabbagh A, Khetsuriani N, Ogbuanu I (2011) Increased transmission and outbreaks of measles, European Region, 2011. Wkly Epidemiol Rec 86: 559-564.

10. Muscat M (2011) Who gets measles in Europe? J Infect Dis 204 Suppl 1: S353-365.

11. Parker Fiebelkorn A, Redd SB, Gallagher K, Rota PA, Rota J, Bellini W, Seward J (2010) Measles in the United States during the postelimination era. J Infect Dis 202: 1520-1528.

12. Rota PA, Brown K, Mankertz A, Santibanez S, Shulga S, Muller CP, Hubschen JM, Siqueira M, Beirnes J, Ahmed H, Triki H, Al-Busaidy S, Dosseh A, Byabamazima C, Smit S, Akoua-Koffi C, Bwogi J, Bukenya H, Wairagkar N, Ramamurty N, Incomserb P, Pattamadilok S, Jee Y, Lim W, Xu W, Komase K, Takeda M, Tran T, Castillo-Solorzano C, Chenoweth P, Brown D, Mulders MN, Bellini WJ, Featherstone D (2011) Global distribution of measles genotypes and measles molecular epidemiology. J Infect Dis 204 Suppl 1: S514-523.

13. Moss WJ, Griffin DE (2012) Measles. Lancet 379: 153-164.

14. Uzicanin A, Zimmerman L (2011) Field effectiveness of live attenuated measles-containing vaccines: a review of published literature. J Infect Dis 204 Suppl 1: S133-148.

15. Cutts FT, Grabowsky M, Markowitz LE (1995) The effect of dose and strain of live attenuated measles vaccines on serological responses in young infants. Biologicals 23: 95106.

16. Cheng WY, Yang CF, Hou YT, Wang SC, Chang HL, Chiu HY, Wang ET, Wu HS (2011) Imported measles and 
implications for its elimination in Taiwan. Emerg Infect Dis 17: 1523-1526.

17. Cilla G, Montes M, Artieda J, Pineiro L, Arriola L, PerezTrallero E (2011) Measles genotypes D4 and G3 reintroduced by multiple foci after 15 years without measles virus circulation, Gipuzkoa, the Basque Country, Spain, March to June 2011. Euro Surveill 16: 19997.

\section{Corresponding author}

Dr Nestor Sosa, MD

Director

Gorgas Memorial Institute for Health Studies

Apartado Postal 0816 - 02593

Panama, Panama

Telephone: 507-527-4811

Fax: 507-527-4889

Email:drnsosa@gmail.com

Conflict of interests: No conflict of interests is declared. 